\title{
Sloth biology: an update on their physiological ecology, behavior and role as vectors of arthropods and arboviruses
}

D.P. Gilmore?,

C.P. Da Costa ${ }^{1}$ and

D.P.F. Duarte ${ }^{1}$

\author{
${ }^{1}$ Departamento de Fisiologia e Farmacologia, \\ Universidade Federal de Pernambuco, Recife, PE, Brasil \\ ${ }^{2}$ Institute of Biomedical and Life Sciences, University of Glasgow, \\ Glasgow, UK
}

\section{Correspondence}

C.P. Da Costa

Departamento de Fisiologia e

Farmacologia, UFPE

50670-901 Recife, PE

Brasil

Fax: +55-81-271-8350

E-mail: cpc@npd.ufpe.br

Research supported by CNPq and FACEPE. D.P. Gilmore is the

recipient of a Royal Society and

Brazilian Academy of Sciences

International Exchange fellowship.

\section{Introduction}

Received April 12, 2000 Accepted August 7, 2000

\section{Abstract}

This is a review of the research undertaken since 1971 on the behavior and physiological ecology of sloths. The animals exhibit numerous fascinating features. Sloth hair is extremely specialized for a wet tropical environment and contains symbiotic algae. Activity shows circadian and seasonal variation. Nutrients derived from the food, particularly in Bradypus, only barely match the requirements for energy expenditure. Sloths are hosts to a fascinating array of commensal and parasitic arthropods and are carriers of various arthropodborne viruses. Sloths are known reservoirs of the flagellate protozoan which causes leishmaniasis in humans, and may also carry trypanosomes and the protozoan Pneumocystis carinii.

We have recently reviewed the literature in terms of the physiological studies carried out on two- and three-toed sloths (1) since Goffart (2) published Function and Form in the Sloth 30 years ago. This paper is intended to update research undertaken since that time on other aspects of sloth biology. Topics covered include the general ecology, behavior, nutrition and digestion as well as the large range of arthropods associated with sloths and the number of viruses they transmit.

Of the two living species of Megalonychidae, Choloepus hoffmanni is found from the lowland forest to the higher altitudes of mountain forests south of Nicaragua through Central America and in Colombia, Venezu- ela, French Guiana, Ecuador, Peru, Brazil and Bolivia. The species is still common, but its numbers are fewer in areas where it coexists with the three-toed sloth. Its weight averages $5.72 \pm 0.69 \mathrm{~kg}$ (3). The hair of this species is lighter than in Choloepus didactylus. The ears are rounded and thickened and almost always covered with hair. It has been reported (4) that the eyes can be partially retracted when the lids are tightly closed. This may make the sloth appear pop-eyed during periods of stress or prior to the onset of aggressive behavior when the lids appear to rise from their orbits. Choloepus didactylus is found from the delta of the Orinoco River west to the upper drainage of this river in Colombia, east through French Guiana and in Brazil to the State of Maranhão. Its weight is $6.07 \pm 1.09 \mathrm{~kg}$ (3). It is less well- 
adapted to the drier areas than is Bradypus. In 1992 its presence was recorded in the Yungas region of Bolivia, considerably further south than previously reported (5).

The distribution of the present day sloths was illustrated in the earlier review (1). Bradypus torquatus (the maned sloth) is regarded as an endangered species, its numbers having fallen catastrophically with the destruction of the Atlantic coast forest (Mata Atlântica) in southeastern Brazil. According to Wetzel (3), Bradypus torquatus is possibly the South American mammalian species closest to extinction. Remnant populations are thought to survive in the remaining fragments of the Mata Atlântica from Rio Grande do Norte to Bahia, Espírito Santo, and Rio de Janeiro.

Wetzel (3) reported that Bradypus torquatus appears to be smaller than Choloepus, with adults weighing about $4 \mathrm{~kg}$, but Pinder (6) found the maned sloth to range from 4.05 to $6.20 \mathrm{~kg}$ in weight and from 520 to $672 \mathrm{~mm}$ in length. Infants were characterized by the absence of a mane. The widely distributed Bradypus variegatus has an average weight of $4.34 \pm 0.85 \mathrm{~kg}$, whereas the pale-throated three-toed sloth, Bradypus tridactylus, averages $4.01 \pm 0.28 \mathrm{~kg}$ (3).

It is obvious that human activity is the major threat to the continued existence of sloths in particular localities. One of the few natural predators of the animals is the Harpy eagle (Harpia harpyja). Izor (7) gathered the skeletal remains of about 83 prey items from a Harpy eagle nest site in southwestern French Guiana and found that sloths (predominantly Choloepus) and cebid monkeys each constituted about one third of all the food prey. Beebe (8) found remnants of Bradypus tridactylus in the stomach of a large anaconda and in a margay cat. Izor discussed the reasons why sloths might constitute such a high proportion of the Harpy eagle's diet. The usual hunting time for this bird is around sunrise when ambient temperature is at its minimum. At this time too the activity of both two- and three-toed sloths is minimal and the animals, slowed by thermal stress, are high in the trees seeking early sunshine to warm themselves (9). The sloths are thus susceptible to aerial attack by the Harpy eagles which have enormously developed feet and talons. The formidable weapons enable the birds to strike and dislodge sloths from the canopy without losing flight speed.

\section{General ecology and behavior}

Neither Bradypus nor Choloepus are able to tolerate cool temperature latitudes. Nevertheless, both Bradypus griseus = variegatus and Choloepus hoffmanni have been recorded living at altitudes higher than $2400 \mathrm{~m}$ in the Braulio Carrillo National Park (Costa Rica) and a single specimen of Choloepus hoffmanni was collected in Costa Rica from the Turrialba Volcano at $3328 \mathrm{~m}$ where the annual rainfall is $2284 \mathrm{~mm}$ and the maximum annual temperature only $16.3^{\circ} \mathrm{C}(10)$. At higher altitudes the coat of Choloepus is appreciably thicker than in individuals living at lower altitudes (11). Bradypus has a lower thermal conductance than Choloepus because only the former has a dense woolly undercoat below the coarse guard hairs, and Bradypus also has a lower limit of thermoneutrality $\left(24^{\circ} \mathrm{C}\right)$ than does Choloepus $\left(18^{\circ} \mathrm{C}\right)$. According to McNab (11), the cold temperature tolerance of some extinct ground sloths probably stemmed from their great size, larger muscle mass than their arboreal counterparts, thick fur and a constant food supply. This enabled them to extend their range into temperate regions of the Americas.

The hair of sloths is of special interest because of the presence of symbiotic algae in it at certain times. Sloths have two distinct coats, one made up of long coarse, but silky, hair which provides the distinctive color of the animal and the other made up of short fine and soft fur lying underneath. A detailed description of the pelage of both Choloepus and Bradypus was provided by Beebe (8) 
and updated by Goffart (2). The color pattern is especially variable in Bradypus, with some adult males possessing a "saddle mark" of black and white, yellow and black or bright orange. It has been reported (4) that in Choloepus hoffmanni the general coloration of the body hair may be almost blonde, buff, tan or light brown in adults. Shading of the hair from light to dark over the head and back is sometimes observed. The facial hair is characteristically lighter than that of the body and Choloepus hoffmanni lacks the dark shoulder and forearm markings seen in Choloepus didactylus. Interestingly, the abdominal hair is parted in the middle, flowing outwards. This allows for the efficient runoff of water from the abdomen of the animal which spends much of its life hanging upside down.

In Bradypus the long hairs are oval-shaped with broad and narrow sides and a width of $0.4 \mathrm{~mm}$. The soft underfur is round and never more than $0.05 \mathrm{~mm}$ in diameter, being colorless, translucent and usually wavy. In the two-toed sloth the long hairs are quite different, having a maximum width of 0.16 $\mathrm{mm}$ and being nearly all fluted with a series of longitudinal ridges and furrows (3-9) running the length of each hair and attenuating near the tip. This longitudinal fluting appears to be unique amongst mammals. Wujek and Cocuzza (12), who examined the hair of sloths using scanning electron microscopy, found that the intricate cuticular scales in the two-toed sloth's hair are interrupted by grooves. Freeze-fractured sections indicated that the cuticle is not continuous around the shaft. In Bradypus the hairs are more complex and beneath the cuticle there are scattered fusi (shallow air pockets) which do not, however, extend entirely unbroken along the shaft. Wujek and Cocuzza believe that the morphological differences in the hair lend further support to the assignment of the two genera of living sloths to separate families.

During the dry season the hair of the sloths usually has a dirty brown coloration, but during long periods of rain it may show a very appreciable greenish tinge brought about by the increased presence of symbiotic algae. According to Britton (13), the algae may already be present in the hair of animals only a few weeks old and it has been suggested that they provide camouflage for the sloths, while obtaining shelter for themselves (see 14). The algae have distinct distribution patterns in Choloepus and Bradypus, lying longitudinally along the grooves in the former and in short lateral tongues or lines in the latter. Algae representing four phyla have been cultured (15) from Bradypus, these being Chlorophyta, Chrysophyta, Cyanophyta and Rhodophyta. It has also been confirmed that the algae found on the coat of Bradypus tridactylus lie between the cuticle scales (14) and that the hair changes with age in apparently all species of Bradypus. Young hairs are white, gray, brownish or black and do not possess the deep cracks seen in older hairs. The first traces of algae appear on these young hairs as tiny dots or extremely narrow transverse lines. Older hairs have larger, wider algal colonies and obvious deep transverse cracks. When wet these cracks close considerably, but when dry give the effects of beads on a string. The oldest hairs are badly deteriorated with the spongy cuticle worn off on one side exposing the full length of the cortex. In the older hairs living algae are absent. It was suggested (14) that either the algae colonize the very narrow cracks in young hairs or the algae themselves initiate the cracks. The hair of all three $\mathrm{Bra}$ dypus species readily absorb water, but those of Choloepus do not. Aiello (14) was unsure as to whether in Choloepus the algae rested upon the surface of the spongy cuticle in the grooves or were embedded in it. They were, however, confined to the grooves. Aiello discussed the different possibilities as to why sloth hair has evolved in such a way to encourage algal colonization. She does not believe that camouflage or thermal insula- 
tion are the only or necessarily the more important reasons and suggested that the algae may provide nutrition or a particular trace element. Lack of healthy algal colonies could thus provide an explanation why $\mathrm{Bra}$ dypus does not survive long in captivity.

Meritt (4) points out that mutual grooming of the hair in captive sloths is rare, and only seen between infant and mother. Selfgrooming takes place in response to food left on the face, nose, or wedged on the roof of the mouth. In the latter instance food may be dislodged with a foreclaw, while that on the face and nose is removed with a claw or brushed off with a forelimb footpad. Animals were frequently seen to scratch the sides of the abdomen, lower neck and neck region adjacent to the chest. This type of grooming, lasting 1 to $6 \mathrm{~min}$, usually took place at night in sloths that had been inactive for an extended period of time. When the sloth was in a resting position, its back supported the upper neck near the junction of the jaws and the external genitalia was the area most frequently scratched.

A large number of workers have extensively studied the flora and fauna on Barro Colorado Island in the Canal Zone of Panama where it appears that the three- and, to a lesser extent, the two-toed sloths are major items $(23 \%)$ of the mammalian biomass of the tropical rainforest (16). It has also been estimated that on Barro Colorado Island the two-toed sloth has a larger home range than the three-toed animal and exists at roughly only $25 \%$ of its density (16). In 1973 Sunquist and Montgomery (17) examined the movement and activity patterns of 6 adult Choloepus hoffmanni and 15 adult Bradypus variegatus on Barro Colorado Island. The twotoed sloths were observed to be nocturnal and their activity patterns were similar to those reported for other terrestrial nocturnal herbivores. No crepuscular activity was recorded, but activity started from an hour after sunset. Activity levels then decreased as the night progressed to a nadir just after midnight. This was followed by a resurgence in activity about $2 \mathrm{~h}$ before dawn. Most activity had ceased by sunrise, but some animals were occasionally active until midmorning. Howarth and Toole (18) also investigated the circadian rhythm of activity over nine days in a two-toed sloth (Choloepus hoffmanni) using a movement-sensitive cage. Although the animal was in captivity, it was housed under natural illumination. It was observed that the sloth began to move at about 19:30 h (shortly after sunset) with peak activity continuing for 2 to $3 \mathrm{~h}$ thereafter. Movement only ceased at approximately $5: 30 \mathrm{~h}$ (sunrise). This nocturnal nature of activity in Choloepus hoffmanni was also reported by Meritt (4). In contrast, Sunquist and Montgomery (17) found that three-toed sloths (Bradypus infuscatus $=$ variegatus) were active during both day and night. With the exception of a 7-h period centered approximately at dawn, average levels were about equal throughout the $24 \mathrm{~h}$. Three-toed sloths averaged 10.1 total hours of activity/ day compared to 6-7 $\mathrm{h}$ in the two-toed species. Although many of the periods of activity were of short duration, the bulk of the time spent moving around was in bouts of continuous activity lasting two or more hours. It was also confirmed that three-toed sloths (Bradypus variegatus), at least when in captivity, were active throughout the afternoon, with the period of greatest activity between noon and 18:00 h, and the periods of deepest sleep between 6:00 $\mathrm{h}$ and noon (19). More recently, the movements of 6 adult male three-toed sloths (Bradypus variegatus) in captivity were recorded every $5 \mathrm{~min}$ over a 48-h period (20). The animals moved about significantly more when it was dark, particularly between $21: 00 \mathrm{~h}$ and midnight, than at other times.

Working at the same location on Barro Colorado Island, Montgomery and Sunquist (9) studied habitat selection and its use by Choloepus hoffmanni and Bradypus variegatus. They found that home ranges were 
usually less than two hectares, and that threetoed sloths were less particular about the tree species which they used, being located on 40 of 91 trees that grew in two study areas. Individual three-toed sloths were found in the same tree on successive days $38 \%$ of the time, whereas in contrast two-toed sloths were seldom located on the same tree on successive days. Two-toed sloths were found in about $20 \%$ of the trees used by Bradypus. The latter, however, tended to choose trees more for the extent to which the crown was exposed to sunlight while Choloepus was most likely to be found in trees with masses of lianas in their crowns. It was discovered (9) that the tendency of three-toed sloths to use trees with open crowns was related in part to the vertical movements the animals made in the forest canopy into and out of direct sunlight according to their thermoregulatory needs.

In a recent paper, Chiarello (21) has reported some interesting information about patterns of activity in the maned sloth $\mathrm{Bra}$ dypus torquatus. Three animals were studied using radiotelemetry over a 14-month period in the Santa Lucia Ecology Preserve (7 $\mathrm{km}$ from Santa Teresa) in the State of Espírito Santo. This area lies between 550 and $1000 \mathrm{~m}$ above sea level and the vegetation consists of subtropical moist lower mountain forest. Individual home ranges varied from 0.6 to 6 hectares and sloths were recorded to travel an average of only $24 \mathrm{~m}$ during any 24-h period. Most of this movement occurred during daylight indicating a predominantly diurnal rhythm of activity. The sloths started to move about and feed between 7:00 and 8:00 h, and rested or slept for only an average of $74 \%$ of the time during the day. The time spent active is about double that observed in other studies. Self-grooming also took place for short periods of time. Daytime activity was maximum around 10:00-11:00 h, although feeding remained relatively constant between 9:00 and 14:00 h. Chiarello suggested that the preva- lent diurnal activity behavior of these maned sloths, and the comparatively long period spent moving about, were probably related to the lower ambient temperatures found in the Atlantic forest compared to other more equatorial regions where the animals have been studied. During the dry season (April to September) the sloths spent significantly less time resting and more time feeding than in the wet season (October to March), when day range lengths were reduced. Pinder (22) had previously observed that in the Poço das Antas Biological Reserve in Rio de Janeiro the activity of Bradypus torquatus was essentially nocturnal, with the sloths starting to move about after sunset and little action taking place during daylight hours. However, it is estimated that the temperature is around $10^{\circ} \mathrm{C}$ warmer in the Rio de Janeiro location, which may account for this difference between the two populations.

Beebe (8) never observed more than one adult three-toed sloth in the same tree as another and Montgomery and Sunquist (23) reported it to be very rare for sloths of the same species to be on one tree together. However, an agonistic encounter between two three-toed sloths (Bradypus variegatus) was observed at La Selva Biological Station in Costa Rica (24). An adult male sloth was high in a Cecropia tree eating leaves, when another male ascended and struck the first from below with a forefoot. The animals then began to pummel each other with their forelegs while vocalizing frequently before disengaging, after which the intruder descended and left the vicinity. The whole incident lasted no longer than $3 \mathrm{~min}$.

\section{Nutrition and digestion}

Goffart (2) described in detail the anatomy of the sloth digestive tract, summarizing studies carried out by earlier workers including Beebe (8) and Britton (13). More recently esophageal pressure profiles in Bradypus variegatus were investigated by Duarte et al. 
(25). Three functionally distinct regions were found: a cranial one located at $7.3 \pm 1.4 \mathrm{~cm}$, a caudal one located at $27.0 \pm 2.6 \mathrm{~cm}$, and another between these two. The resting pressures of the cranial and caudal esophageal sphincters were $20.5 \pm 6.8$ and $12.8 \pm 4.9$ $\mathrm{mmHg}$, respectively. The maximal pressure and its duration (mean $\pm \mathrm{SD}$ ) were $40.4 \pm$ $12.4 \mathrm{mmHg}$ and $2.8 \pm 0.75 \mathrm{~s}$ (cranial) and $35.7 \pm 11.5 \mathrm{mmHg}$ and $4.3 \pm 1.2 \mathrm{~s}$ (caudal), respectively. These findings for the three distinct regions were correlated with the results of a histological study (26).

Luis da Mota et al. (27) carried out a morphological and histochemical investigation of the intestinal tract in the three-toed sloth (Bradypus tridactylus $=$ variegatus $)$. The animals studied were two male and two female specimens captured in the forests outside Recife. It was found that the intestine averaged $198.5 \mathrm{~cm}$ in length and that it was almost totally uniform in diameter, although very dilated in the rectal region. The wall of the intestine was seen to consist of mucosa, submucosa, tunica muscularis and serosa. The mucosa itself could be subdivided into epithelium, a lamina propria (consisting of loose connective tissue containing collagenous and elastic fibers amongst which were fibroblasts, small lymphocytes, eosinophils and macrophages) and a thin layer of smooth muscle (the muscularis mucosae). The submucosa was also made up of loose connective tissue and the tunica muscularis of an inner circular and outer longitudinal layer of smooth muscle between which ganglion cells of Auerbach's plexus were present. The serosa was seen to consist of mesothelial cells resting on delicate fibrous connective tissue. The duodenum was recorded as averaging $9.5 \mathrm{~cm}$ in length with a thicker wall than the remainder of the intestine. On the luminal surface of its proximal third were five or six distinct longitudinal folds and in the medial third packed circular folds running in a sinuous fashion. The folds in the distal third were small and irregular. From the submucosa of these folds numerous leafshaped villi containing lamina propria, small blood vessels and smooth muscle cells projected into the intestinal lumen. The epithelium of these villi contained tall columnar cells with a striated border and also some goblet cells. In the duodenum the crypts of Lieberkühn were shallow and Brunner's glands were confined exclusively to the lamina propria and were more abundant in the proximal region. The muscularis mucosae was poorly developed and the submucosa was straight and consisted of relatively dense connective tissue containing large blood vessels.

The same authors (27) also reported that the jejunum possessed circular folds on its luminal surface and that these resembled those seen in the duodenum except that the villi were longer and narrower. The villi were lined with a simple columnar epithelium with a well-developed striated border; goblet cells were scattered throughout the epithelium. As in the duodenum the crypts of Lieberkühn were shallow, but sometimes branched. In the ileum there were alternate smooth areas, occasional branched folds and small sinuous rugae. The mucosa was lined with a simple columnar epithelium containing goblet cells. The villi in this region became shorter distally near the large intestine. The crypts of Lieberkühn contained more goblet cells at their base than in the jejunum.

In the sloth the large intestine has been seen to consist of a short colon and a dilated rectal pouch; no cecum exists. On the inner surface of the colon alternate smooth areas and longitudinal folds are present (27). No villi are apparent and the surface epithelium is again composed of columnar cells with a striated border, but these are less prominent than in the small intestine. More goblet cells are present than in the jejunum and ileum. The luminal diameter of the rectal pouch is very large in comparison to the rest of the intestine and the markedly thickened walls possess several well-developed folds of vary- 
ing size running in a sinuous manner. The mucosa is similar to that seen in the colon, but the muscularis mucosae is very well developed. The tunica muscularis, containing many elastic fibers, is also thicker in the rectal pouch than in any other part of the intestine. Some further details regarding the histology of the rectum in Bradypus variegatus were supplied by Padovan et al. (28), who also emphasized that water absorption mainly occurs in this region of the digestive tract.

It has been observed (27) that the longitudinal and circular folds seen in the intestine of the three-toed sloth have the same histological structure as those seen in most other mammals. Argyrophilic and argentaffin cells are found throughout the entire length of the sloth intestine, but Paneth cells are absent. It was suggested (27) that the absence of a cecum is probably compensated for by the enzyme activity that takes place in the large sacculated stomach and that the slow absorption of nutrients may be assisted by the numerous villi present in the small intestine.

Concentrations (ng/g wet weight of tissue) of 4 neuropeptides have been measured (29) in the colon of Choloepus didactylus and found to be as follows: VIP, $275 \pm 26$; PHI, $225 \pm 18$; substance P, $97 \pm 17$, and met-enkephalin, $128 \pm 32$. Mechanical and intracellular electrical activity has also been recorded (29) in the smooth muscle of the colon. Spontaneous mechanical activity was found to consist of 5 to 6 individual phasic contractions during each 4-min period. The resting membrane potential averaged $58 \pm 4$ $\mathrm{mV}$ and the amplitude of the inhibitory junction potential ranged from 1-3 $\mathrm{mV}$ with no accompanying circular muscle relaxation. It was suggested (29) that the absence of a prominent inhibitory innervation may be associated with low concentrations of VIP and $\mathrm{PHI}$ and might account for the sloth's in vivo pattern of colonic motility.

As pointed out by Goffart (2), the different species of Bradypus live principally on the leaves, flowers, shoots and fruit of the ymbahuba (embauba) tree (Cecropia sp). It was once believed that these were the primary if not only source of food for these animals, but Montgomery and Sunquist (23), who studied Bradypus variegatus, found that the animals ate the leaves of not less than 28 different trees and 3 vines. It was observed that the choice of leaves eaten by an individual sloth was influenced by those eaten by its mother during the 6-month period when it was carried by her. Leaves eaten from other trees included those from the various species of Ficus, the wild plum (Spondus lutea), Protium panamense, Poulsenia armata, Eriobotyra japonica, Luhea and Bombax longiflorum. In the Santa Lucia Ecology Preserve (Espírito Santo) Chiarello (30) reported that $99 \%$ of the diet of Bradypus torquatus was composed of leaves. These were predominantly young ones and especially so during the wet season when they were more abundant. Chiarello listed all the plants consumed and also reported the percentage of time spent feeding on each. The most important species making up the diet were Prunus sp, Ficus sp, Micropholus venulosa, and the vine Mandevilla sp. Flowers and fruit of Mandevilla sp and Cecropia hololeuca were consumed. The diet of these maned sloths, as in other species, was highly selective as less than $4 \%$ of the 476 trees recorded as present were utilized as food. Moreover, the species mostly chosen were not those present at highest density.

In captivity, citrus fruits, lettuce and bananas are accepted by three-toed sloths, although it is very difficult to maintain the animals alive for long periods of time. It has been argued (23) that three-toed sloths may starve to death on a full stomach if the wrong selection of food is made, due to the slow digestion of leaves. The same workers also estimated that sloths on Barro Colorado Island cropped only $0.63 \%$ of the total annual leaf production of the forest, much less than the $7 \%$ attributed to insects. Manganese is an 
element naturally occurring in the leaves eaten by three-toed sloths, but is not assimilated. Nagy and Montgomery (31), by measuring the increase in concentration of manganese between the food ingested and the feces produced, estimated that three-toed sloths (Bradypus variegatus) on Barro Colorado Island in the Panama Canal Zone consumed $15 \mathrm{~g}$ dry food $(\mathrm{kg} /$ day $)$ during the dry season. This is higher than the earlier estimate of $6.9 \mathrm{~g} \mathrm{~kg}^{-1}$ day $^{-1}$ (32) calculated from measurements of oxygen consumption and the time budgets of free-living animals. It is also appreciably more than that of $5.1 \mathrm{~g} \mathrm{~kg}^{-1}$ day $^{-1}$ calculated (23) from measurements of feces production rates in the field with an assumed assimilation efficiency of $50 \%$.

Choloepus is much easier to maintain in captivity outside its normal habitat than $\mathrm{Bra}$ dypus, and survives indefinitely on Cecropia, bananas, oranges, figs and even meat and fish. Colonies of Choloepus hoffmanni and Choloepus didactylus were kept healthy in Chicago on a wide variety of food including diced apples, oranges, bananas, lettuce, spinach, bread, sweet potatoes, green beans, peas, canned salmon, freshly ground smelt and ground meat sprinkled with a powder containing vitamins and minerals $(4,33)$. Meritt (4) observed that daily food consumption by individual adult two-toed sloths ( $\mathrm{Cho}$ loepus hoffmanni) averaged $350 \mathrm{~g} /$ day, i.e., $85 \mathrm{~g} / \mathrm{kg}$ body weight. This was during a period of acclimation after capture. In fully acclimated sloths food intake averaged 250 $\mathrm{g} /$ day, dropping off a little just before the periodic defecation, when $30 \%$ of the body weight could be lost. This is not surprising, as it has also been recently found (34) that the proportion of body mass contained in the gut ranges from 17 to $37 \%$, values similar to those reported in earlier studies. It was noted (33) that in captivity the period between evacuations varied from 3 to 8 days and that the feces were always deposited in the same spot. In confined two-toed sloths, the longest period between eliminations was observed to be 6 days (4). In free-living Bradypus variegatus, about $56 \mathrm{~g}$ (dry weight) of feces was seen to be deposited every 8 days in a shallow depression punched out by the sloth with its tail on the forest floor within $3 \mathrm{~m}$ of a tree used by the animal (9). It was also reported (23) that two-toed sloths, which lack a proper tail, usually left their feces on the soil or litter surface. In the two-toed sloth the feces were found to be firm and were passed as single pellets or as a large compacted mass of compressed individual pellets (33). It was also observed (9) in threetoed sloths fitted with gastric fistulae that young leaves were digested more rapidly and that the oldest leaves which were digested fastest were those from trees that were ranked highest in use by some sloths. The rates at which leaves were digested were much slower than those reported for other herbivorous mammals and the rate of passage of food was the slowest recorded for any mammal. Around two and a half days were required for the passage of $5 \%$ of glass beads $3 \mathrm{~mm}$ in diameter fed to the animals, and 50 days before $95 \%$ of them were passed. Foley et al. (34) believe that these results are questionable, because the beads probably accumulate and are retained in the pre-pyloric region of the stomach. Foley et al. (34) examined digestion near Cayenne, French Guiana, in 6 captive specimens of Bradypus tridactylus fed exclusively on Cecropia palmata. Digestive passage was measured by use of various markers dosed in liquid form. The particulate digestive phase was marked with three rare earth elements administered in solution and the solute digestive phase with three complexes of ethylenediaminetetraacetic acid. After the animals were killed at pre-determined intervals following feeding, ranging from 6 to $288 \mathrm{~h}$, samples were collected from 10 regions of the gut. By analysis of the marker content in the different parts of the digestive tract it was possible to construct cumulative excretion curves. These indicated that the mean reten- 
tion time of the particulate and solid digestive markers was around $150 \mathrm{~h}$. Seventythree per cent of this retention was in the stomach and $17 \%$ (because of storage of feces) in the rectum. From these observations it was argued (34) that there is now little support remaining for the earlier view (13) that a diverticulum acts to prolong the retention of food. Foley et al. (34) observed that the proportion of short-chain fatty acids present in the stomach was broadly similar to that present in other foregut fermenters eating fibrous diets, but the rate of fermentation measured in vitro was very slow in comparison to the latter animals. It was therefore postulated (34) that the slow fermentation rate is most likely due to the lignified nature of the Cecropia foliage the animals were fed, but perhaps also to the low body temperature of sloths. The same investigators further argued that although digestion in sloths is characterized by both slow rates of passage and fermentation of a large volume of digesta in the forestomach yielding energy only gradually, this is feasible because of the sloths' low energy expenditure.

$\mathrm{McNab}$ (35) examined the energetics of a large variety of arboreal leaf eaters and confirmed that the xenarthrans have low basal rates varying from 40 to $60 \%$ of the expected values. Earlier the same author (35) had found that the basal metabolic rate for Choloepus was only $45 \%$ and that of Bradypus only $42 \%$ of the values expected from their respective body weights. He suggested the following explanations as to why these low basal metabolic rates may exist: a) In arboreal mammals muscle mass makes up only a relatively small proportion of the body which therefore has a larger proportion of tissue with low metabolic rate. b) Leaves have only a low available caloric density. Since the maximal daily bulk that can be processed is limited, the energy available from this diet is low. c) A number of toxic substances including alkaloids, phenols and terpenes are present in leaves. As mentioned earlier, the low basal metabolic rate in leaf-eating mammals may reduce the absorption of these substances.

The mean energy expenditure for Bradypus has been estimated to be $95.5 \mathrm{kcal} /$ day (32). This does not agree with another study (23) reporting that the daily intake of food provided energy of only about $54.4 \mathrm{kcal}$. $\mathrm{McNab}$ (32) suggested that the difference between these estimates of energy expenditure and the energy provided by the food eaten may reflect higher rates of decay in the feces than assumed by other workers (9).

\section{Arthropods associated with sloths}

Sloths act as hosts to a wide variety of arthropods, which include biting and bloodsucking flies such as mosquitoes and sandflies, triatomine bugs, lice, ticks and mites. However, there is a noticeable absence of fleas and anoplurans associated with the animals, although the flea Polygenis atopus, which feeds primarily on rodents and marsupials, has been recorded from Bradypus infuscatus $=$ variegatus in Venezuela (36). Sloths also carry a highly specific community of commensal beetles, mites and moths. Waage and Best (37) investigated in detail a number of the different arthropods associated with Bradypus tridactylus, Bradypus variegatus and Choloepus didactylus in the vicinity of Manaus, while Wolda (38) carried out a comprehensive study of the seasonal distribution of sloth moths in Panama.

Up to 6 species of ticks of the genus Ambylomma have been recorded from both two- and three-toed sloths in Central and South America, but the opinion is (37) that only Ambylomma geayi and Ambylomma varium are truly specialized for living on sloths as these ticks are rarely found on other hosts. The other four ambylommid ticks apparently only occur on sloths accidentally. It was also observed (37) that adult males of Ambylomma geayi may remain on their hosts for more than three weeks, but the females 
leave after engorging to oviposit. Infestation with ticks can be extremely high. At the Instituto Nacional de Pesquisas da Amazonia in Manaus, Waage and Best (37) recorded that $99 \%$ of three-toed and $86.7 \%$ of twotoed sloths carried Amblyomma spp. There was no apparent correlation between the numbers of ticks at any life stage per sloth and the seasonal difference in rainfall in Manaus and nothing is known about the host-finding behavior of either Ambylomma geayi or Ambylomma varium. Pinder (6) recorded many ticks (Ambylomma varium) underneath the thighs of maned sloths (Bradypus torquatus) examined in the Poço das Antas Biological Reserve in the State of Rio de Janeiro; one specimen of Boophilus sp was also found. Interestingly, Pinder reported that $83 \%$ of the ticks were males and on $60 \%$ of the sloths only male ticks were present.

A number of commensal beetles, mites and moths are found in association with sloths and their dung. Adults of several scarab beetle species are frequently found in the fur of three-toed sloths, but have not been reported to be associated with Choloepus. Waage and Best (37) discovered more than 980 such beetles (Trichilium adisi) in the fur of a single sloth (Bradypus variegatus) collected on Curari Island in the Central Amazon region, and stated that beetles of the genus Uroxys have been recorded from sloths in Bolivia, Brazil, Colombia and Panama. The scarab beetles occur near the elbow or on the flanks behind the knees buried deep inside the fur. Waage and Best observed that although the numbers of scarab beetles fluctuated during the year, seasonal factors affecting the populations were unknown. Beetle larvae feed on sloth dung and the adults may utilize this as food too. The presence of Trichilium sp has been reported in the underfur of the lower back and thighs of Bradypus torquatus (6). Wolda and Estribi (39) identified and counted sloth beetles (Uroxys gorgon) captured in light traps at five locations in Panama, although in three of these very few beetles were caught. On Barro Colorado Island in Gatun Lake, higher numbers of beetles were captured during the rainy season. In Fortuna (a dam site on the Chiriqui River and a relatively non-seasonal region) there was a tendency towards a bimodal distribution in the numbers captured which, however, were comparatively low as the species was also rare in the area. Wolda and Estribi suggested that the beetles have dispersal flights at the beginning and end of the rainy season and that part of the population might enter reproductive diapause and disperse from the sloths to sites with some moisture and then resume reproduction at the end of the dry season and return to the sloths. In Fortuna, where the rain falls either as drizzle or in tropical storms, flight activity (and therefore capture) of the beetles could be affected. On the other hand, beetles caught in Fortuna may have been merely dispersing from elsewhere.

Waage and Best (37) identified three species of macrochelid ascarine mites (Macrocheles impae, Macrocheles uroxys and Macrocheles lukoschusi) in the anus and inside the rectum of three-toed sloths from Curari Island and Manaus. They also reported earlier findings of blood-sucking mites (Liponissus inheringi, Lobalges trouessarti and Edentalges bradypus) on three-toed sloths collected in southern Brazil. Fain (40) recorded the mite Edentalges choloepi on Choloepus didactylus. An interesting relationship apparently exists between the mites Macrocheles impae and Macrocheles uroxys and the sloth beetles Uroxys besti and Trichilium adisi on which they occur. Only adult female mites have been observed and only occasionally on Trichilium adisi. Waage and Best (37) postulated that the role of the beetles may be to transport the adult female mites from a diminishing dung pile to another sloth. The third macrochelid mite ( $\mathrm{Ma}$ crocheles lukoschusi) was not found in association with the scarab beetles.

Moths of the subfamily Chrysauginae 
spend their lives as adults in the fur of sloths, particularly the three-toed species. It was found (6) that the most common ectoparasite on maned sloths (Bradypus torquatus) was Cryptoses sp which were found hiding in the fur. It has been suggested (38) that there the sloth moths may receive some protection from avian predators and possibly find nutrients in secretions of the sloths' skin and/or the algae present on the fur. Waage and Best (37) reported that some three-toed sloths may carry in excess of 120 moths; lower numbers may occasionally be seen on twotoed sloths. They also pointed out that there is considerable sympatry amongst moth species found on sloths and that several different species may coexist on the same animal. Waage and Best (37) concluded that the most striking characteristic of the various arthropods associated with sloths is the large number of coprophagous species which appear to depend on the animals for phoresis. They speculated that the great diversity of phoretic coprophages on sloths has evolved because of a strong selection for phoresis and the ideal conditions existing for transport on the sloths. Larval stages of the moths live in and feed on the sloths' dung, the adult females presumably leaving the sloths during defecation to deposit their eggs there. Waage and Best described how early larval stages of the pyralid sloth moth Cryptoses choloepi are covered by a light silken web; later this becomes a long silken tube within which the larva feeds and then pupates. Newly emerged moths migrate to the forest canopy to locate a sloth. Waage and Best also reported that the sex ratio of the moth Cryptoses choloepi is 1:1 at emergence, but on Bradypus the females are outnumbered 3:1 by males. This led Waage and Best to suggest that females are possibly lost from the sloth-bound population when they leave to oviposit. The life histories of sloth moths other than Cryptoses choloepi are less well known, but several are believed to be broadly similar to this species. However, Bradypodi- cola hahnelli is found deep inside the sloth's fur where it is able to move very rapidly; most adults have truncated wings (presumably broken by abrasion) and are thus incapable of flying. Waage and Best (37) also pointed out that the population sizes and dynamics of the sloth moths are dependent on the availability of sloth dung and thus on the density of these mammals; seasonal factors such as rainfall may have secondary effects.

Wolda (38) investigated the seasonal distribution of Cryptoses choloepi at three locations in Panama where it is associated with both Bradypus infuscatus and Choloepus hoffmanni. He used light traps to collect moths on Barro Colorado Island, in Las Cumbras (a residential area near Panama city) and at Fortuna. Wolda observed that although there were some notable differences between the years in the seasonal patterns of abundance of sloth moths on Barro Colorado Island, numbers were generally very low during the early part of the dry season (January to mid-March). They then increased to peak around mid-May before declining again towards the end of the rainy season. During the dry season most moths were captured close to the ground, but during the rainy season more were caught in the canopy. At the end of the year approximately equal numbers were collected from both situations. At Las Cumbras a broad abundance of moths was again seen during the early part of the rainy season, but numbers then continued to increase to peak in January. Numbers fell only during the very end of the rainy season or in the first half of the dry season. At Fortuna, during the early part of the year when the light trap was in the canopy, more moths were captured than later in the year when it was transferred close to the ground. Wolda believes that although seasonal changes in rainfall may have little direct effect on moth numbers, indirectly this might be very important. Wolda (38) also speculated that a rise in sloth mortality 
during periods of increased cloudiness (due to interference with the animals' thermoregulatory mechanisms) might result in more moths becoming air-borne in search of new hosts. Furthermore, after a peak in sloth reproduction (around September) there would be consequently more sloths defecating on the forest floor making it easier for the moths to find hosts.

\section{Arboviruses and other diseases associated with sloths}

Seymour (41) has reviewed the role of sloths as the possible hosts to a whole variety of arthropod-borne viruses (arboviruses), citing work carried out in Belém (Brazil), and in Panama. However, whether or not sloths are essential or only incidental to the natural cycle of an arbovirus, their long experimental viremias are remarkable and Seymour suggests that these may be due to the animals' low metabolic rate.

Antibodies to the mosquito-borne Venezuela encephalitis virus, which can prove fatal in horses, have been found in Bradypus variegatus and Choloepus hoffmanni collected in Panama. Seymour (41) concluded that Bradypus in particular is a potential source of infection for this virus as it develops higher concentrations of it in blood, detectable for longer periods of time than for most other forest species tested. In contrast, two-toed sloths had low concentrations of the Venezuelan encephalitis virus in blood; the duration was unreported. Another infection carried by mosquitoes (the Mayaro virus) causes sporadic outbreaks of human febrile illness in forested areas of South America and Trinidad. Although sloths can be infected in the laboratory, this, according to Seymour, only occasionally takes place in the wild. Similarly, sloths would appear to play no important role in the transmission of the yellow fever virus. Although the animals can be inoculated with it, the infection patterns are erratic and there are no apparent signs of illness.

Other investigations (42) in Panama have indicated that there is a high prevalence of the St. Louis encephalitis virus in sloths, particularly Choloepus. This virus, which can cause human encephalitis, occurs throughout the Americas from Canada to Argentina but in the tropics is presumed to be enzootic and probably only causes sporadic human illness (42). Seymour (41) suggested that although sloths may be important hosts for the St. Louis encephalitis virus, they are presumably only infrequently infected and gradually build up antibodies over a lengthy period of time; infected animals show no overt signs of disease. It has been found (42) that captive two- and three-toed sloths responded to inoculation with the St. Louis encephalitis virus with remarkably long-lasting viremias of high titer. The duration of detectable viremia ranged from 7 to 27 days (median 11) in Choloepus hoffmanni and from 13 to 24 days (median 18) in Bradypus variegatus. Interestingly, the onset of experimentally induced St. Louis encephalitis viremias was delayed and the maximum titer levels were depressed in two sloths concurrently infected with the Bradypus- 4 virus and an agent related to the Changuinola virus. When mosquitoes (Culex pipiens quinquefasciatus) were allowed to feed on infected sloths $80 \%$ were able to transmit St. Louis encephalitis to chicks or mice after 1427 days intrinsic incubation. Whether, however, sloths play an important role in the transmission of the St. Louis encephalitis virus to humans is as yet uncertain. Somewhat surprisingly, a young three-toed sloth housed with its experimentally infected nonlactating mother became infected with the St. Louis encephalitis virus, indicating that contact transmission is possible. Another virus antigenically related to the St. Louis encephalitis virus and to yellow fever is the Ilheus virus which occasionally causes human febrile illness and encephalitis. However, Seymour (41) has reported that as anti- 
bodies to the virus were found in only one of 167 three-toed and just one of 99 two-toed sloths tested in Panama, this is a good indication that these animals are not important vectors of the disease.

Seymour (41) has reported that the Oropouche virus (apparently transmitted by Culicoides midges) has been isolated from a small number of sloths (Bradypus tridactylus) in Brazil. The virus is known to cause periodic epidemic febrile illness amongst humans in the State of Pará. Sloths are also possible reservoirs for the Utinga virus also carried by Culicoides midges and by Anopheles mosquitoes. Seymour stated that the virus has been isolated from Bradypus tridactylus and that Bradypus variegatus and Choloepus hoffmanni from Panama have been found to be positive for the virus too. However, the antibody results concerning wild sloths are confused by possible crossreactions with the Utive and Pintupo viruses; all three, which are members of the Simbu serogroup, are sloth-specific. Antibodies to the Utive virus have been found in two- and three-toed sloths collected in Panama.

According to Seymour (41), different phleboviruses (carried by phlebotomine sandflies) have on occasion been identified in sloths. Strains of the Changuinola virus have been isolated from both two- and three-toed sloths in Panama and this complex of viruses appears to be sloth-specific. Seymour et al. (43) also reported the isolation of the previously unidentified infectious agent (the Bradypus-4 virus) from a male sloth (Bradypus variegatus) captured in Panama. Seymour et al. (43) believe this to be an RNA virus with a lipidcontaining envelope; it was negative when tested against 216 world-wide arboviruses.

Seymour (41) finally concluded that the wide variety of arboviruses isolated from sloths can be characterized according to antibody and virus isolation data as being slothspecific (Utinge, Utive and Changuinola viruses), incidental in sloths (such as the Venezuelan encephalitis viruses), or others (in- cluding the St. Louis encephalitis and Oropouche viruses) for which the role sloths play in the natural cycles is as yet uncertain. Simultaneous productive infections appear to be possible in these animals.

It has been reported (44) that the phlebotomine sandfly is also a known vector of the flagellate protozoan Leishmania which causes cutaneous leishmaniasis in humans. All species belonging to the genus Leishmania are morphologically similar, except for minor differences in their size. It was also pointed out (45) that sloths are proven or suspected reservoirs of at least five Leishmania species belonging to the Leishmania braziliensis complex of the subgenus Viannia, i.e., Leishmania b. colombiensis, Leishmania $b$. equatoriensis, Leishmania b. guyanensis, Leishmania b. panamensis and Leishmania $b$. shawi, responsible for human cutaneous and/or mucosal leishmaniasis.

Shaw et al. (46) noted that in the eastern region of the State of Pará in Brazil, south of the Amazon River, Leishmania b. shawi frequently infected humans, whereas north of the river Leishmania b. guyanensis was the most common cause of human leishmaniasis. Leishmania b. colombiensis has also been isolated from humans, sandflies and a two-toed sloth (Choloepus hoffmanni) captured in Panama (47). Herrer and Christensen (48) found that in Panama Choloepus hoffmanni showed the highest infection rate with Leishmania b. guyanensis amongst all forest mammals in which natural Leishmania infections were demonstrated. Of Leishmania b. guyanensis infections in 95 sloths, $33.7 \%$ were seen in the skin only, $42.1 \%$ in the viscera (including blood and bone marrow) only, and $24.2 \%$ in both regions. Infection rates were proportional to the age of the animals, rates being higher in young sloths than in juveniles and adults. Herrer and Christensen (48) suggested that sloths probably become infected during the first few months of life and remain infected for a long time, although since the parasites disappear 
from some animals the disease might be selflimiting. Herrer and Christensen (48) concluded that Choloepus hoffmanni is the principal reservoir for Leishmania b. guyanensis in Panama and that because the animals survive infections without evidence of pathology this indicates a long association which appears to have evolved into a commensal relationship. Ecological and epidemiological investigations (48) also revealed a close relationship between geographical distribution of human cutaneous leishmaniasis and the presence of leishmanial infection in two-toed sloths. Furthermore, it was found (49) that Choloepus didactylus was a reservoir for Leishmania b. guyanensis in French Guiana in areas where dermal leishmaniasis is frequent among humans.

Christensen et al. (50) carried out precipitin tests on blood taken from over 2500 engorged female sandflies collected in the forest alongside the Torquato Tapajós highway near Manaus. The most prevalent sandfly collected was Lutzomyia umbratilis and xenarthrans were found to be the most common hosts of this insect and also of Lutzomyia anduzei. Interestingly, the overwhelming majority of sandflies feeding on sloths were found on Choloepus didactylus. Christensen et al. (50) therefore decided that this would implicate two-toed sloths as the major reservoirs of Leishmania braziliensis in the northern Amazon region and also probably throughout these animals' total range (i.e., from Nicaragua to central Brazil). Shaw (51) also concluded that in this region the twotoed sloth is the major vertebrate host of Leishmania b. panamensis, although Bradypus variegatus is occasionally infected as well; here the sandfly Lutzomyia trapidoi is the vector for the disease. In Costa Rica Leishmania herreri has been isolated from both Choloepus hoffmanni and Bradypus variegatus. All the Leishmania of xenarthrans that have been studied in sandflies are peripylarians, a type of Leishmania found in New World mammals; it was suggested that they may have evolved in the group.

Many striking similarities exist between Leishmania and parasites of the genus Endotrypanum which have at least three distinct stages in their life cycle. In sloths they exist as intra-erythrocytic epimastigotes (Endotrypanum schaudinni) or trypomastigotes (Endotrypanum monterogeii) while the promastigote stage is seen in sandflies and in culture. Shaw (51) reported that Endotrypanum schaudinni has been recorded in Choloepus didactylus and Choloepus hoffmanni and in Bradypus variegatus and Bradypus tridactylus in Costa Rica, Panama, French Guiana and Brazil. In all instances, however, far more two- than three-toed sloths were infected with this parasite. Endotrypanum monterogeii has been isolated from twotoed sloths (Choloepus hoffmanni) in Costa Rica. Another previously undescribed erythrocytic parasite was identified in a two-toed sloth (Choloepus didactylus) captured in French Guiana (52). The organism, morphologically related to the Babesiidae family, was named Babesia choloepi and is the first Babesia species to be identified in a xenarthran.

Flagellates of the genus Trypanosoma, which occur as trypomastigotes in their vertebrate host, have been found in a variety of xenarthrans including sloths. Shaw (51) reported that Trypanosoma mesnilbrimonti and Trypanosoma preguici were isolated from Choloepus didactylus in northern Brazil and French Guiana. Trypanosoma preguici has been identified from Choloepus hoffmanni in both Costa Rica and Panama and from Bradypus variegatus in Costa Rica. Trypanosoma leewenhoeki occurred in both Choloepus hoffmanni and Bradypus variegatus in Costa Rica and Panama. Moreover, Trypanosoma leewenhoeki has been isolated from Choloepus hoffmanni inhabiting the Pacific coast of Colombia (53). Although Trypanosoma cruzi has been recorded from Choloepus hoffmanni and Bradypus variegatus in Panama, Shaw (51) believes they are 
accidental hosts and not reservoirs. Shaw (51) discussed in some detail the relationship of infections to host behavior and habitat, and pointed out that if a vector has a narrower habitat preference than its vertebrate host there will consequently be uninfected populations of the latter. Shaw pondered whether differences in behavior and the wider habitat range of Choloepus compared to Bradypus might at least partly explain some of the observed variations in hemoflagellate infection rates between twoand three-toed sloths. Herrer and Christensen (48) examined 498 sloths captured in the Panamanian forest over a 10 -year period and, interestingly, found that $19.3 \%$ were infected with Leishmania braziliensis, 29.5\% with Endotrypanum schaudinni, 19.0\% with Trypanosoma rangeli, and just one animal with Trypanosoma cruzi.

Toxoplasmosis has also been identified by Shaw and Lainson (54) in a two-toed sloth (Choloepus didactylus), although in this instance it was uncertain as to whether the infection had been acquired in captivity or in the wild. Nevertheless, these authors did point out that the disease has been recorded in other xenarthrans (the nine-banded armadillo Dasypus novemcinctus and lesser anteater Tamandua tetradactyla). The sloth, collected from the Barcarena district of Pará, had been in the laboratory for 66 days when it was found to be infected with Toxoplasma gondii. Hamsters and mice inoculated with homogenates of liver and spleen from this animal died within 7 days. The largest number of parasites was present in the liver, lungs and spleen, but endozoites were also detected in stained smears of blood, heart, kidneys and peritoneal exudate.

The protozoan Pneumocystis carinii, which causes lung infections in a wide variety of mammals and is implicated as a cause of pneumonia in patients with AIDS, has been found in the lungs of sloths. The disease has been identified in a three-toed sloth (Bradypus tridactylus) in Pará, Brazil (55).
The animal had been kept in captivity close to a group of coatimundis (Nasua narica) which carried the infection. Some time later an apparently healthy two-toed sloth (Choloepus didactylus) also captured in Pará was autopsied. Abundant division stages of Pneumocystis were found in the lungs. It was concluded (55), however, that human contact with infected wild animals in their natural environment is so slight that there would be little chance of direct transmission, although there is an obvious risk to those handling captive animals. This is borne out by the identification (56) of Pneumocystis carinii in the lungs of 23 zoo animals that died in the Netherlands over an 11-year period. One of these was a three-toed sloth (Bradypus tridactylus) that had been imported from Surinam three months earlier. Pneumocystis has also been isolated from a female three-toed sloth (Bradypus variegatus) collected from the Panamanian jungle (57).

Diniz and Oliveira (58), who carried out a 20-year retrospective study on 17 two-toed and 34 three-toed sloths in the São Paulo Zoo, noted that malnutrition accounted for $45.7 \%$ and respiratory disease for $13.8 \%$ of the clinical disorders recorded. Digestive dysfunction was responsible for $12.3 \%$ of the illnesses just under half of these involving the presence of Ascaris spp. Bacteria including Escherichia coli, Citrobacter freundii and Salmonella enteritidis were isolated from the feces and/or organs of 13 sloths.

Interestingly, parasites have even been recorded in dung balls of the extinct Shasta ground sloth (Nothrotheriops shastensis) collected from Rampart Cave at the western end of the Grand Canyon in Arizona. These animals appear to have been completely herbivorous and Schmidt et al. (59) identified juveniles of two different nematode species, two morphotypes of coccidian oocysts and eggs of two species of helminths in their feces. The dung was dated to $10,000 \pm 80$ years and, like the sloths, these parasites are now also believed to be extinct. 


\section{References}

1. Gilmore DP, Da-Costa CP \& Duarte DPF (2000). An update on the physiology of two- and three-toed sloths. Brazilian J ournal of Medical and Biological Research, 33: 129-146.

2. Goffart M (1971). Function and Form in the Sloth. Pergamon Press, Oxford, New York, Toronto, Sydney, Braunschweig.

3. Wetzel $R$ (1985). The identification and distribution of recent Xenarthra (= Edentata). In: Montgomery GG (Editor), The Evolution and Ecology of Armadillos, Sloths and Vermilinguas. Smithsonian Institution Press, Washington and London, 5-21.

4. Meritt DA (1985). The two-toed sloth, Choloepus hoffmanni Peters. In: Montgomery GG (Editor), The Evolution and Ecology of Armadillos, Sloths and Vermilinguas. Smithsonian Institution Press, Washington and London, 333-341.

5. Le Pont F \& Desjeux P (1992). Présence de Choloepus hoffmanni dans les Yungas de La Paz (Bolivie). Mammalia, 56: 484485.

6. Pinder L (1993). Body measurements, karyotype, and birth frequencies of maned sloth (Bradypus torquatus). Mammalia, 57: 43-48.

7. Izor RJ (1985). Sloths and other mammalian prey of the Harpy eagle. In: Montgomery GG (Editor), The Evolution and Ecology of Armadillos, Sloths and Vermilinguas. Smithsonian Institution Press, Washington and London, 343-346.

8. Beebe W (1926). The three-toed sloth Bradypus cuculliger cuculliger Wagler. Zoologica, 7: 1-67.

9. Montgomery GG \& Sunquist ME (1978). Habitat selection and use by two-toed and three-toed sloths. In: Montgomery GG (Editor), The Ecology of Arboreal Folivores. Smithsonian University Press, Washington, DC, 329-359.

10. Urena HM, Chacon CR, Faerron AS \& Lizano ST (1986). Hallazgo de Bradypus griseus y Choloepus hoffmanni (Edentata: Bradypodidae) en tierras altas de Costa Rica. Revista de Biologia Tropical, 34: 165166.

11. McNab BK (1985). Energetics, population biology, and distribution of Xenarthrans, living and extinct. In: Montgomery GG (Editor), The Evolution and Ecology of Armadillos, Sloths and Vermilinguas. Smithsonian Institution Press, Washington and London, 219-232.

12. Wujek DE \& Cocuzza JM (1986). Morphology of hair of two- and three-toed sloths (Edentata: Bradypodidae). Revista de Biologia Tropical, 34: 243-246.

13. Britton SW (1941). Form and function in the sloth. Quarterly Review of Biology, 16: 13-34 and 190-207.

14. Aiello A (1985). Sloth hair: unanswered questions. In: Montgomery GG (Editor), The Evolution and Ecology of Armadillos, Sloths and Vermilinguas. Smithsonian Institution Press, Washington and London, 213-218.

15. Thompson RH (1972). Algae from the hair of the sloth Bradypus. J ournal of Phycology, 8 (Suppl): 8 (Abstract 2:35).

16. Eisenberg J F \& Thorrington RW (1973). A preliminary analysis of a neotropical mammal fauna. Biotropica, 5: 150-161.

17. Sunquist ME \& Montgomery GG (1973). Activity patterns and rates of movement of two-toed and three-toed sloths (Choloepus hoffmanni and Bradypus infuscatus). J ournal of Mammalogy, 54: 946-954.

18. Howarth ST \& Toole J F (1973). Some observations on the circadian rhythm of Choloepus hoffmanni, the two-toed sloth. Laboratory Animal Science, 23: 377-379.

19. Galvão de Moura Filho A, Huggins SE \& Lines SG (1983). Sleep and waking in the three-toed sloth, Bradypus tridactylus. Comparative Biochemistry and Physiology, 76A: 345-355.

20. Lucena RLBG, Silva EM, Montenegro $P$, Oliveira J $r$ WM, Silva IGC, Viana FMM, Silva IG, Duarte DPF, Da-Costa CP \& Silva VL (1996). Padrão de deslocamento em preguiças Bradypus variegatus em cativeiro. Abstracts of the XI Annual Meeting of the Federação de Sociedades de Biologia Experimental, Caxambu, MG, Brazil, August 21-24, 225 (Abstract 34.029).

21. Chiarello AG (1998). Activity budgets and ranging patterns of the Atlantic forest maned sloth Bradypus torquatus (Xenarthra: Bradypodidae). J ournal of Zoology, 246: 1-10.

22. Pinder L (1985). Obsenvações preliminares da preguiça de coleira (Bradypus torquatus) (Illiger 1811) (Edentata Bradypodidae). XII Brazilian Congress of Zoology, Universidade Estadual de Campinas, Campinas, SP, Brazil, J anuary 27February 1, 290-291.

23. Montgomery GG \& Sunquist ME (1975). Impact of sloths on neotropical energy flow and nutrient cycling. In: Medina E \& Golly F (Editors), Trends in Tropical Ecology; Ecological Studies IV. Springer Verlag, New York, 69-98.
24. Greene HW (1988). Agonistic behavior by three-toed sloths, Bradypus variegatus. Biotropica, 21: 369-372.

25. Duarte DPF, Félix $\mathrm{CH}$, Da-Costa $\mathrm{CP}$, Padovan IP \& Chou CC (1988). Avaliação funcional da motilidade esofageana da preguiça (B. variegatus). Abstracts of the III Annual Meeting of the Federação das Sociedades de Biologia Experimental, Caxambu, MG, Brazil, J une 29-J uly 3, 186 (Abstract 5.12)

26. Carvalho GL, Padovan IP, Falabella PA, Silva Filho VC, Penha MRC, Duarte DPF, Félix CH, Chou CC \& Da-Costa CP (1988). Estudo morfométrico do esofago da preguiça (Bradypus variegatus). Abstracts of the III Annual Meeting of the Federação das Sociedades de Biologia Experimental, Caxambu, MG, Brazil, J une 29-J uly 3, 187 (Abstract 5.14).

27. Luis da Mota D, George LL, Pinheiro PPB $\&$ Pinheiro NL (1989). Some morphological and histological studies on the intestinal tract of the Brazilian sloth (Bradypus tridactylus). Gegenbaurs Morphologisches J ahrbuch, 2: 367-377.

28. Padovan IP, Valenca EM, Falabella P, Penha MRC, Duarte DP, Félix $\mathrm{CH}$, Chou CC, Da-Costa CP \& Silva Filho VC (1988). Estudo histofisiológico do reto da preguiça (B. variegatus). Abstracts of the III Annual Meeting of the Federação das Sociedades de Biologia Experimental, Caxambu, MG, Brazil, J une 29-J uly 3, 187 (Abstract 5.13).

29. Koch TR, Go VLW, Roddy DR, Lucas DL, Michener SR \& Szurszewski JH (1985). Neuropeptide concentrations and electrophysiological properties of colonic smooth muscle from the two-toed sloth. Digestive Diseases and Sciences, 30: 777 (Abstract).

30. Chiarello AG (1998). Diet of the Atlantic forest maned sloth Bradypus torquatus (Xenarthra: Bradypodidae). J ournal of Zoology, 246: 11-19.

31. Nagy KA \& Montgomery GG (1980). Field metabolic rate, water flux, and food consumption in three-toed sloths (Bradypus variegatus). J ournal of Mammalogy, 61: 465-472.

32. McNab BK (1978). Energetics of arboreal folivores: physiological problems and ecological consequences of feeding on an ubiquitous food supply. In: Montgomery GG (Editor), The Ecology of Arboreal Folivores. Smithsonian University Press, Washington, DC, 153-162.

33. Meritt DA (1973). Edentate diets. II. Two- 
toed sloths. Laboratory Animal Science, 23: 543-545.

34. Foley WJ, Engelhardt Wv \& Charles-Dominique $P$ (1995). The passage of digesta, particle size and in vitro fermentation rate in the three-toed sloth Bradypus tridactylus (Edentata: Bradypodidae). J ournal of Zoology, 236: 681-696.

35. McNab BK (1982). The physiological ecology of South American marsupials. In: Mares MA \& Genoways HH (Editors), Mammalian Biology in South America. Vol. 6. Special Publication Series, Pymatuning Laboratory of Ecology, University of Pittsburgh, Pittsburgh, 187-207.

36. Tipton VJ \& Machado-Allison CE (1972). Fleas of Venezuela. Brigham Young University Science Bulletin Biological Series, 17: 1-115.

37. Waage JK \& Best RC (1985). Arthropod associates of sloths. In: Montgomery GG (Editor), The Evolution and Ecology of Armadillos, Sloths and Vermilinguas. Smithsonian Institution Press, Washington and London, 297-311.

38. Wolda H (1985). Seasonal distribution of sloth moths Cryptoses choloepi Dyar (Pyralidae; Chrysauginae) in light traps in Panama. In: Montgomery GG (Editor), The Evolution and Ecology of Armadillos, Sloths and Vermilinguas. Smithsonian Institution Press, Washington and London, 313-318.

39. Wolda $H \&$ Estribi M (1985). Seasonal distribution of the large sloth beetle Uroxys gorgon Arrow (Scarabaeidae; Scarabaeinae) in light traps in Panama. In: Montgomery GG (Editor), The Evolution and Ecology of Armadillos, Sloths and Vermilinguas. Smithsonian Institution Press, Washington and London, 319-322.

40. Fain A (1964). Edentalges choloepi sp. $n$. acarien parasite cuticole du paresseux didactyla Choloepus didactylus (L.) (Psoroptidae: Sarcoptiformes). Zeitschrift für Parasitenkunde, 25: 103-107.

41. Seymour C (1985). Sloths as hosts of arboviruses. In: Montgomery GG (Editor), The Evolution and Ecology of Armadillos, Sloths and Vermilinguas. Smithsonian Institution Press, Washington and London,
269-278.

42. Seymour C, Kramer LD \& Peralta PH (1983). Experimental St. Louis encephalitis virus infection of sloths and cormorants. American J oumal of Tropical Medicine and Hygiene, 32: 854-861.

43. Seymour C, Kramer LD \& Peralta PH (1983). Viruses isolated from Panamanian sloths. American J ournal of Tropical Medicine and Hygiene, 32: 1435-1444.

44. Arias J R \& Freitas RA (1978). Sobre os vetores de leishmaniose cutânea na Amazônia Central do Brasil. 2: Incidência de flagelados em flebotomos selváticos. Acta Amazonica, 8: 387-396.

45. Franco $A M R$, Momem $H$, Naiff RD, Moeira CFS, Deane MP \& Grimaldi G (1996). Enzyme polymorphism in Endotrypanum and numerical analysis of isoenzyme data. Parasitology, 113: 39-48.

46. Shaw J J, Ishikawa EAY, Lainson R, Braga RR \& Silveira FT (1991). Cutaneous leishmaniasis of man due to Leishmania (Viannia) shawi in Pará State, Brazil. Annales de Parasitologie Humaine et Comparee, 66: 243-246.

47. Kreutzer RD, Corredor A, Grimaldi J r G, Grogl $M$, Rowton ED, Young DG, Morales A, McMahon-Pratt D, Guzman H \& Tesh RB (1991). Characterization of Leishmania colombiensis sp. $\mathrm{n}$ (Kinetoplastida: Trypanosomatidae), a new parasite infecting humans, animals, and phlebotomine sandflies in Colombia and Panama. American J ournal of Tropical Medicine and Hygiene, 44: 662-675.

48. Herrer A \& Christensen HA (1980). Leishmania braziliensis in the Panamanian twotoed sloth, Choloepus hoffmanni. American J ournal of Tropical Medicine and Hygiene, 29: 1196-1200.

49. Gentile B, Le Pont F, Pajot FX \& Besnard R (1981). Dermal leishmaniasis in French Guiana: the sloth (Choloepus didactylus) as a reservoir host. Transactions of the Royal Society of Tropical Medicine and Hygiene, 75: 612-613.

50. Christensen HA, Arias J R, de Vasquez AM $\&$ de Freitas RA (1982). Hosts of sandfly vectors of Leishmania braziliensis guyanensis in the Central Amazon of Brazil.
American J ournal of Tropical Medicine and Hygiene, 31: 239-242.

51. Shaw JJ (1985). The hemoflagellates of sloths, vermilinguas (anteaters) and armadillos. In: Montgomery GG (Editor), The Evolution and Ecology of Armadillos, Sloths and Vermilinguas. Smithsonian Institution Press, Washington and London, 279-292.

52. Dedet J P, Veilly M, Robin Y, Bonnevie O \& Landau I (1988). Babesia choloepi N. sp. (Apicomplexa, Piroplasmida), parasite du paresseux a deux doigts, Choloepus didactylus (Linne, 1758) (Xenarthra, Bradypodidae) en Guiana Francaise. Annales de Parasitologie Humaine et Comparee, 63: 16-21.

53. Travi BL, Zea A \& D'Alessandro A (1989). Trypanosoma (Herpetosoma) leewenhoeki in Choloepus hoffmanni and Didelphis marsupialis of the Pacific coast of Colombia. J ournal of Parasitology, 75: 218-224.

54. Shaw JJ \& Lainson R (1973). Toxoplasmosis of the two-toed sloth, Choloepus didactylus, in Brazil. J ournal of Parasitology, 59: 206-207.

55. Lainson R \& Shaw JJ (1975). Pneumocystis and histoplasma infections in wild animals from the Amazon region of Brazil. Transactions of the Royal Society of Tropical Medicine and Hygiene, 69: 505-508.

56. Poelma FG (1975). Pneumocystis carinii infections in zoo animals. Zentralblatt für Bakteriologie, Parasitenkunde, Infektionskrankheiten und Hygiene, 46: 61-68.

57. Yonushonis WP, Elwell MR, Lawyer PG \& Rabago EC (1986). Infection of a threetoed sloth (Bradypus variegatus) by a Pneumocystis-like organism in Panama. J ournal of Wildlife Diseases, 22: 572-575.

58. Diniz LDSM \& Oliveira MA (1999). Clinical problems of sloths (Bradypus sp. and Choloepus sp.) in captivity. J ournal of Zoo and Wildlife Medicine, 30: 76-80.

59. Schmidt GD, Duszynski DW \& Martin PS (1992). Parasites of the extinct Shasta ground sloth, Nothrotheriops shastensis, in Rampart Cave, Arizona. J ournal of Parasitology, 78: 811-816. 